\title{
Unethical Practices of Advertising in Bangladesh: A Case Study on Some Selective Products
}

\author{
Sheikh Majedul Huq, Md. Nekmahmud*, Mst. Shuly Aktar \\ Department of Marketing, Begum Rokeya University, Rangpur, Bangladesh \\ Email address: \\ argonmkt@yahoo.com (Md. Nekmahmud),msabrur@yahoo.com (Mst. S. Aktar), huqsajib@yahoo.com (S. M. Huq)
}

\section{To cite this article:}

Md. Nekmahmud, Mst. Shuly Aktar, Sheikh Majedul Huq. Unethical Practices of Advertising in Bangladesh: A Case Study on Some Selective Products. International Journal of Economics, Finance and Management Sciences. Vol. 4, No. 1, 2016, pp. 10-19.

doi: $10.11648 /$ j.ijefm.20160401.12

\begin{abstract}
Ethics is the code of conduct of Business. It is a highly significant considerable issue in case of any advertising. But the uses or degree of competition of unethical practices of advertising are increasing in Bangladesh than the before. Most of the multinational, global and local companies use some unethical and misleading advertising to increase their immediate sales volume of products by providing untruthful and over colored information about their products qualities and ingredients. For this reason, standard and branded companies can't achieve customer's satisfaction and their desired goal. The present study attempts to make the customer awareness regarding unethical practices of advertising in Bangladesh. Beside the study examines the status of unethical practices of adverting in Bangladesh and identify the ways of overcoming the problems of unethical practices. In this study, seven (7) identified products of different companies which are involved with unethical practices of advertising have been selected as a sample. Qualitative techniques are gathered and presented in a descriptive way. In Bangladesh maximum companies are not following the proper ethical standards in advertising and unable to maintaining the Consumer Rights. For this reason, consumers are deceived due to false and unrealistic advertising copy. Informative, truthful, creative, effective, realistic, beautiful and social advertising makes a good effect on the socio economic condition of any country.
\end{abstract}

Keywords: Advertising, Advertising Copy, Ethics, Unethical Advertising, Consumer Rights, Bangladesh

\section{Introduction}

In recent years, Unethical advertising has become a highly discussed topic in the Business world. There has been much interest among the consumers, business owners, managers, advertising agencies and academics regarding truthful and untruthful advertising. Businesses are in the game to make money and advertising can go a long way towards selling a particular product. Advertising has played a major role in consumer marketing and has enabled companies to meet communication and other marketing objectives. Typically, advertising is used to inform, persuade, and remind consumers (Singh \& Vij, 2007) [40]. Companies use advertisements to make current and potential customers aware of the features and benefits of their brand. Today's society is very concerned about creative, meaningful and truthful advertising.

Advertising is such an interesting field in the marketing industry. However, the advertising should be an effective attraction and creative to attract the customer. The development of the advertising industry has been increasing year by year to provide the latest information about the product. Advertising is not only promoting the product but it is also can promote the services, entertainment, found and lost, land and more. Advertising can be channeled through media such as the internet, radio, television, pamphlets, banners, billboards, newspapers, magazine and so on according to the creativity of an advertising agency. However, at present, the fastest media attention, feedback, and the concern of many people is through the internet (Bin Nooh et al., 2014) [10]. Recently, the advertisers did not pay attention and awareness on their way of distributing messages to the people. As we learn that, advertising can bring positive and negative impact, according to its words. Advertising is considered unethical when it degrades rival's product or substitute product, gives misguiding information, gives false information, concise information that vitally affects human life (e. g., side effects of drugs), makes exaggerated claims, is obscene or immoral or is against broad 
national interest (Singh and Vij, 2007) [40]. Maximum organization and advertising agency in Bangladesh have deceived their customer by making their advertising copy false, confusing and over colored. That's why customized, consumer side, social and other competitive institution also damaged. Because of giving confusing information in different advertising copy, customer's attitude is adverse about those institutions (kabir, 2013) [21]. Advertisers, by giving false information and by trying fraudulent affect the consumer, violate the efficient functioning of the market. They are reducing rivals opportunities to reach consumers. Advertising copy is very important part of advertising. Copy is a sound or message which used in advertising. The main objective of advertising copy is encouraging customers to buy the product. Advertising copy must be ethical. Advertising copy should be right and correct, not deceived or unethical (kotler, 2012) [22]. But the use of unethical advertising is increasing in Bangladesh after 2000 year.

Few marketer and advertiser of Bangladesh don't follow the ethical standard properly. For this reason customer are deceived. It is the high time to make the people aware of those unethical advertising. So it is crying need to conduct studies in this regard and to disclose the real fact.

\section{Objectives of the Study}

The main objective of this study is to make the customer awareness regarding the unethical practices of advertising. Others specific objectives of the study are stated below:

$R O-1$ : To know the present status of advertising in Bangladesh.

$R O-2:$ To increase the awareness about advertising message and contents for saving the respective consumers from the deceive advertising.

RO-3: To develop and explore some probable solutions and recommendations of unethical advertising Practices in Bangladesh.

\section{Review of Relevant Literature}

Some prior research works in unethical advertising that have basically focused on misleading and unethical practice in the advertising sector. They are extensive and critically reviewed to find out the existing research gap which is given below-

Beliefs are the foundations of attitudes that consumers form about advertising. Attitudes toward advertising are operationalized and measured by positive or negative beliefs about advertising.

Jahan (2010) conducted a study on ethics in marketing on Bangladesh perspective: study on few companies of Bangladesh. The researcher conducted to give some approaches about ethical practices that doing by some of the companies in Bangladesh. The research also focuses on the relationship between marketing and business ethics in the business sector and also the ethics based role of marketing programs that occurred in the organization. Companies need to create high ethical standards upon which approach marketing they are participating in ethical marketing [20].

Wilkie and William (1990) agreed that advertising has both positive and negative aspects, but they do not apply to all advertisements. He has listed the "seven sins" charged by advertising's critics [45].

Treise et al. (1994) have investigated that ethic in Advertising: ideological correlates of consumer perceptions. They also investigate the perceptions of familiar advertising controversies \& consumers believe advertising often violates broad ethical norms [43].

Olson (1995) has compiled a list of unintended negative effects of advertising and described these effects in terms of eight criticism categories, drawing on the writings of many social scientists and humanists [32].

Creyer and Ross (1997) also found that a company's level of ethical behavior is an important consideration during the purchase decision; in the USA consumers expect ethical behavior from companies and they were willing to pay higher prices and reward ethical behavior. They did also discover that consumers would still buy products from unethical firms, but only at a lower price - the cost of poor ethics [15].

An earlier study by (Dragon International, 1991; Simon, 1995) has highlighted some important issues in the ethical purchase behavior of consumers [16] [36].

Larkin and Ernest (1977) administered 26 Likert-type statements to 80 college students to measure their attitude toward advertising along four different dimensions: economic effects of advertising, social effects of advertising, ethics of advertising and regulation of advertising [25].

Abideen et al. (1998) have focused on some aspects of unethical practices in advertising used by different advertising agencies and marketing clients. The study reveals that more than three fourth $(76 \%)$ of the consumers believe that most of the advertisements appearing in mass media contain one or more unethical or deceptive practices. These practices are seen more in product advertisements than in service advertisements [2].

Smith (2000) worked that deceptive and misleading online advertising and business practices. The researcher also considers the extent to which digital communications technologies are being used in misleading and deceptive ways to advertise goods and services, and how problems of this nature can be best dealt with [41].

Boulstridge and Carrigan (2000) investigated the response of consumer's to ethical and unethical marketing behavior and identify reasons for consumers to perceive an advertisement as offensive. In contrast, Chinese and Malaysian consumers have given a midpoint offensiveness score to all three items (nudity, indecent language, sexiest image) [12].

Singh and Vij (2007) Wrote an article on socio-economic and ethical implications of advertising - A perceptual study and analyzed in detail the public response to the issues like: targeting children in advertising, 'use of sex in advertisements', 'promotion of materialism through advertising', 'use of comparative advertising', 'ethics in advertising', 'use of celebrities in advertising', 'economic effects of advertising'; and 'public policy on advertising' [40]. 
Usman et al. (2010) examine cultural influence on the general attitude of Pakistani people towards advertising. The researchers analyze the cultural impact on the attitude of people towards advertisements of brands according to product information, social integration and hedonism / pleasure, whereas power distance and masculinity as culture dimensions [44].

Long (2011) has conducted unethical practice in business: the development of a framework for thematic analysis. He also examines reports witnessed by business students, and seeks to make sense of the findings through the development of a framework for analysis [28].

Abbasi et al. (2011) attempted to explore ethical issues in the contemporary advertising campaigns of controversial products in Pakistan from Shari'ah perspective. The level of offensiveness towards advertisements of controversial products was found to be significantly associated with religious perceptions and nature of advertising appeals. Nudity and sexist images as advertising appeals were found to have significant association with the level of offensiveness of the consumers [1].

Singh and Sandhu (2011) have shown that impact of television commercials on the social and moral behavior of indian viewers - empirical evidence. They also examine the prevalence of unethical practices within the business sector operating in the China to Australia tourism market [39].

Liepinyte and Daugèlienè (2012) have conducted that interrelation of misleading adverting and solutions for consumers: legal regulation and institutional background in Lithuania [27].

Singal and Kamra (2012) conducted an empirical research on ethical issues in advertising. In advertising, using media as its vehicle is a pervasive, powerful force shaping attitudes and behavior in today's world. It goes beyond the traditional role of 'fair and truthful' information and portraits obscene, undesirable and unethical scenes, giving a detrimental result especially on the young population of the society. They found out various types of unethical advertisements like advertisements with obscenity and sexual overtone, endorsed by children, surrogate advertising, subliminal advertisements, false and misleading advertisements etc. [38].

Ramachandran and Venkatesh (2012) have found that marketing mix: An area of unethical practices? The researchers intend to develop the model of ethics in marketing. Their emphasis on empirical study in order to show that many unethical marketing practices may be occurring, especially which are related to pricing and advertising practices [33].

Maleki and Pasha (2012) wrote an article about ethical challenges and customers' rights. They find out there are three main orientations in unethical advertising. First the content of the advertising, second the ways that advertisers try to push advertising into the customers' mind and third the methods of tracking individuals' special experiencing over the net with the purpose of promoting companies' products and services [29].

Zetterqvist and Mulinari (2013) the research attempted of misleading advertising for antidepressants in Sweden: a failure of pharmaceutical industry self-regulation. They investigated that Self-regulatory bodies identified numerous code breaches. Nonetheless, they failed to protect doctors from unreliable information on antidepressants, since as many as 247 of 722 (34\%) advertisements breached the industry code. Self-regulatory bodies repeatedly failed to challenge inflated claims of antidepressant efficacy, lending evidence of lax oversight [46].

Kabir (2013) piloted a study on the unethical practices of advertising in Bangladesh and he investigated that maximum companies use unethical practices to increase their sales of products. Most of the companies are not following the ethical standard in advertising [21].

Singh (2014) has accompanied an empirical research on ethical issues and principles related to advertising. Ethical issues in advertising are contiguous to all businesses and customers. His findings indicated that a different number of industries, companies, firms and advertising organizations use unethical in their advertising to promote the product. Some companies use the prospective ethical issues in their advertising to fulfill the legal framework. Today, consumers are more conscious and aware to purchase the products carefully. Therefore, the ethics related to advertising are helpful to build up the positive attitude and confidence of consumers [37].

Bin Nooh et al. (2014) conducted research on the criteria and challenges of unethical advertising. In recent years, there are many ways of advertising to attract customer's attention, including through Billboard, television, radio, newspapers and latest trends of advertising is through Internet by using a social website. However, a lot of advertising brings worried by some of people that concerns towards inappropriate advertising show to the public and seen by all levels of ages including children, teenagers, adults and old folks. Because of this concern, the issues raised up in questioning the inappropriate advertising may bring destructive thoughts to the next generation compared from the past and the present in Malaysia [10].

Ajay (2014) has studied on perception of Indian consumers towards Indian advertisements and observed the development of advertising and its relative effects on the society and the people in particular is considered. The disadvantages of some of the unethical Indian advertisements and their manipulative motives faced by the Indian customers are assessed. He examined to measure the ethical practices of the print and television advertisements in India at present and their relative effects. Advertisements should be decent and not obscene. Sometimes, celebrities endorsing the product and spreading falsehood are also unethical [6].

\section{Methodology of the Study}

This study has been conducted to find out the unethical practices of the advertising in the perspective of Bangladesh. The nature of the study is basically descriptive based on quantitative information. Descriptive study requires a direct interview, observation and massive exploration of secondary 
sources. Both primary and secondary data were gathered in this study. Theoretical part of the study significantly used secondary sources such as review of scholarly journals and reading materials while the quantitative findings and interpretations are depending on primary data.

A significant number of companies are involved with unethical practices of advertising in Bangladesh. But it is difficult to analysis the all companies and its product. So we choose seven (7) identified products of different companies which are involved with unethical advertising practices. Generally two types of the method can be used as sampling unit, one is the probability sampling and other is nonprobability sampling (Malhotra \& Dash, 2011) [30]. We used non- probability sampling techniques because we used the convenience sampling method. Due to time and resource limitation, Energy drink, Fairness Cream, Mango Juice, Shampoo \& Hair Conditional, Vital Nutrient Product, Telecommunication and Face Wash products have been selected as a sample. Because the criteria of unethical advertising are available or match with these seven (7) products. The area of the study was Dhaka and Rangpur city and time was January 2015.

Primary data and information has been collected from different source through observation, interview, discussion and face to face interactions. Secondary data have been taken from various sources such as television advertising, internet, radio, newspaper, Facebook, previous relevant articles, etc. After collecting this data and information the researchers have been analyzed it through qualitative method and presented in a descriptive way. Considering the nature of the study data, the next step was to input the data and analysis the findings.

\section{Measurement of Some Theoretical Related Terms}

\subsection{Ethics}

Ethics (also moral philosophy) is the branch of philosophy that involves systematizing, defending, and recommending concepts of right and wrong conduct. Ethic means moral principles and values that govern the actions and decision of an individual or group (Belch \& Belch, 2009) [9].

\subsection{Business Ethics}

Business ethics (also corporate ethics) are a form of applied ethics or professional ethics that examines ethical principles and moral or ethical problems that arise in a business environment. It applies to all aspects of business conduct and is relevant to the conduct of individuals and entire organizations (Stanford Encyclopedia of Philosophy, 2013) [14]. Business ethics are moral principles that guide the way a business behaves.

Some years ago, sociologist Raymond Baumahart (1968) asked business people, "What do ethics means?" His replies were the Following - [8]

1. Ethics has to do with what many felling tell me, right or wrong.

2. Ethics has to do with my religious benefits.

3. Being ethical is doing what the law requires.

4. Ethics consists of the standard behavior of our society accepts.

So that it can be said that, Business ethics are ethics that refers to the moral rules and regulations governing the business world.

\subsection{Advertising}

Any paid form of no personal presentation and promotion of ideas, goods, or services by an identified sponsor (Kotler, 2009) [24].

Advertising is a form of communication intended to persuade an audience (viewers, readers or listeners) to purchase or take some action upon products, ideas, or services.

Advertising can also serve to communicate an idea to a large number of people in an attempt to convince them to take a certain action.

\subsection{Unethical Advertising}

Unethical advertising is the lack of moral principles; unwilling to adhere to proper rules of conduct in the advertising sector. Unethical advertising is when you promise something you cannot deliver.

Unethical advertising will often distort or misrepresent it's product as well as seek secretive means of cajoling or influencing its target audience.

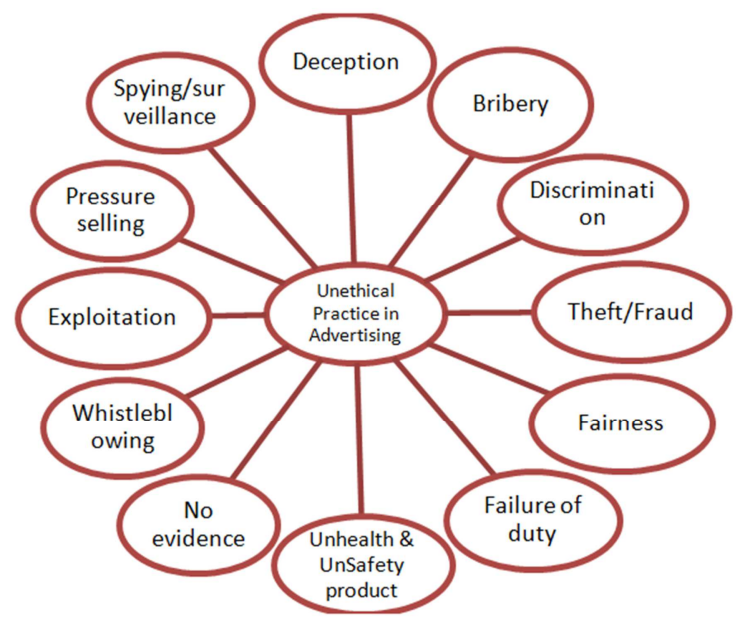

Figure 1. Elements of Unethical Practices in Advertising.

\subsection{Advertising Copy and the Best Elements of Copy}

Copy is the word message or sentence of advertiser. Advertising copy is text of a print, radio, or television advertising message that aims at catching and holding the interest of the prospective buyer, and at persuading him or her to make a purchase all within a few short seconds.

The main purpose of modern advertising copy is to fulfill demand and want of actual and potential customers. Besides, information of advertising copy influence and encourage to 
the potential customer to buy the product.

Advertising copy has to some features. That is showed in to the figure 2 .

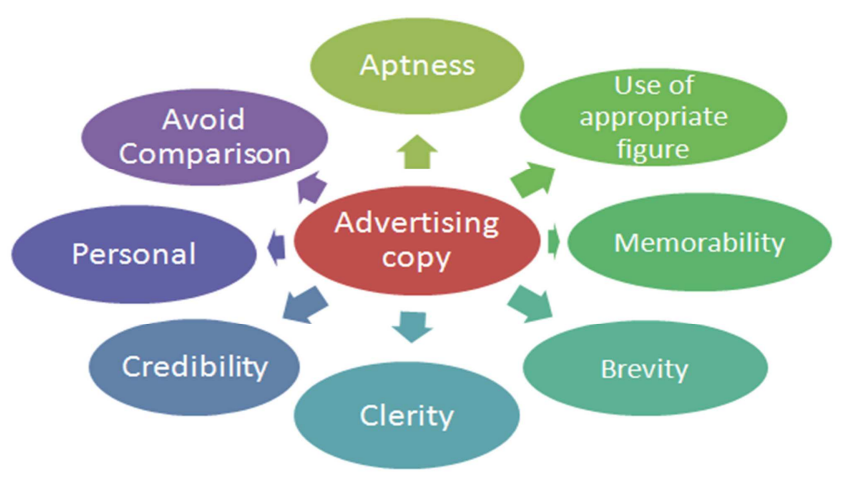

Figure 2. Indicates the best elements of Advertising Copy.

\subsection{Ethical Advertising Copy}

If the quality and characteristics of any product present in advertising copy which are included in that product is called ethical advertising copy that means it will provide the right all information about products (Kabir, 2013) [21].

The right, correct and faithful information must be provided with advertising copy. Such as-

1. Never use a simple untrue advertising message.

2. Principles of the moral order must be applied to the domain of advertising media.

3. Never directly intend to deceive

4. Never use the sexual appeals.

5. Means and techniques of advertising copy must also consider; manipulative, exploitative, corrupt and corrupting methods of persuasion and motivation.

6. Do not distort the truth by implying things that are not so or withholding relevant facts.

7. It should not be presented any over colored information in advertising copy.

8. Presenting any confusing information should be avoided.

9. The right information must be given in the advertisement copy about the quality and characteristic of the product.

10. It should be provided clear, informative and right information about products. So that customers can take the right decision.

11. It confirms the consumer's right.

\subsection{Unethical Advertising Copy}

The Unethical advertising copy is one kind of advertising where it ignores the moral values.

If excess, wrong and confusing information have provided in advertising copy about products then it is called unethical advertising copy (Kabir, 2013) [21]. That means when a company provides attractive and wrong information in their advertising copy to influence to customer buying that product and it wants to earn more profit by selling a huge number of products in short time and deceives customers by those advertising copy, then it is called unethical advertising copy. For which reasons an advertising copy is said unethical that are given below (Kotler \& Armstrong, 2010) [23].

1. Providing wrong information about product in advertising copy.

2. Providing untruthful word or information.

3. Saying over colored about the quality and characteristic of products.

4. Deceiving customers.

5. Snatching customer's right.

\subsection{Rights of Consumer}

Consumer rights are the resonance of the human right's notion, with the demand for consumer protection increasing day by day. The declaration made by former US President John F. Kennedy in 1962 outlined only four basic consumer rights: (1) the right to safety (2) the right to be informed; (3) the right to choose; and (4) the right to be heard.

In keeping pace with the modern world, the formulation of the Consumer Rights Protection Act 2009 is a significant progress towards the protection of the rights and interests of the consumers in Bangladesh. It is designed to protect consumer rights, prevent anti-consumer activities and matters incidental therewith. The essence of the legislation may be succinctly described:

1. Obtaining commodities or services at a price fixed by the authority or at a reasonable price.

2. Right to have safe and pure products.

3. Right to have necessary and correct information about products.

4. Right to be informed of the qualities or defects (if any) of a particular product.

5. Right to know the quantity of the product.

6. Right to know the utility, purity and price of the product.

7. Right to have products or services in right quantity and quality.

8. Right to have a choice among product offerings.

9. Right to have a defense against activities relating to purchase or sale of products by which life or property may be in danger.

10. Right to education about consumer rights and protection.

11. Right to have access to remedy in relation to violations of consumer rights.

\subsection{Usages of Sexual Appeal in Advertising}

Generally, Sex Appeal is very common in advertising in Bangladesh. Sexual appeal is used to gain consumer attention. Sex appeal is used to sell all kinds of things. It is used where it is not even appropriate to the product or service being advertised. The advertisers use women in a wrong way to market their product with displaying a sexy image of a model wearing top T-shirt and short pant, reveal the skin, bikini, using a sexual word in promoting a product such as Viagra and sexual act by a model such as pose on the bed, 
hugging tight with male model which not appropriate viewing by the children and old folks because it will give bad impacts to the children's mind development. Sometimes Sex appeal is used in advertising of a product, but where a particular product is not related to the sex. Using sex appeal Marketing can harm the faithfulness between customers and marketers because customers can understand the intention of marketers behind these manipulative visuals (Giebelhausen \& Novak, 2011) [17]. Sex appeal marketing has negative effects on both genders, especially when the product is not related to sex (Sengupta \& Dahl, 2007) [34]. The findings open the way for further research to explore whether similarly negative effects would occur if sexualized images of women were used to sell ethical causes other than the treatment of animals, for instance, in promoting action to address poverty (Bongiorno et al., 2013) [11].

So, sex appeal is one kind of unethical practice in advertising where sex is not related to the products or services.

\section{Findings of the Study}

As per the data collection and review of the existing relevant literature, the following findings are discussed with the help of a table.

Table 1. Shows the findings of the case study on seven (7) selective products of different companies which are involved with unethical practices in Advertising in Bangladesh.

\begin{tabular}{|c|c|c|}
\hline $\begin{array}{l}\text { Name of the Sample } \\
\text { Products }\end{array}$ & Advertising Copy & Findings of the Study \\
\hline 1. Energy Drink & $\begin{array}{l}\text { "Get energy and power by drinking Energy } \\
\text { Drink" } \\
\text { After drinking of various types of energy drink, } \\
\text { people can get more energy and can complete their all } \\
\text { activities attentively and quickly. Energy drink helps } \\
\text { the people to do all the kinds of work \& it's very } \\
\text { helpful for the health [3]. }\end{array}$ & $\begin{array}{l}\text { Energy drinks contain large number of caffeine and an assortment } \\
\text { of other hazardous ingredients, which is very harmful for our } \\
\text { health and entire society. Consumption of large amounts of } \\
\text { caffeine may lead to serious cardiovascular events, seizures, } \\
\text { Dizziness / syncope, paresthesia (tingling or numbness of the skin), } \\
\text { Increased urination, Insomnia, Headache, Increased urination and } \\
\text { death. Adolescent consumption of caffeine has been linked to } \\
\text { dependence, poor sleep, and possible development problems } \\
\text { (Menci et al., 2013) [31]. So Customer should not attracted by } \\
\text { these types of advertisement. So it can be said that they deceive } \\
\text { their customers by providing wrong information. }\end{array}$ \\
\hline 2. Fairness Cream & $\begin{array}{l}\text { "By using this cream You can be bright, beautiful } \\
\text { and attractive within } 1 \text { week" } \\
\text { There are different types of TV advertising of fairness } \\
\text { creams, which nowadays are being shown on } \\
\text { different TV channels of Bangladesh. That are - (a) A } \\
\text { Young girl is worried about her dark face skin. She } \\
\text { used a fairness cream and became pale within a few } \\
\text { days. (b) A poor dark color gipsy girl used the skin } \\
\text { whitening cream became white and then a rich boy } \\
\text { got married with that poor gypsy girl (c) A girl } \\
\text { changed her face skin from dark to white within three } \\
\text { days after the use of a fairness cream. In single } \\
\text { words, after using fairness cream any girl must be } \\
\text { fair, beautiful, and attractive within a few days. Even } \\
\text { she will be a star and get status in society [3] [4] [5]. }\end{array}$ & $\begin{array}{l}\text { It is impossible to change dark skin color to white with the use of a } \\
\text { fairness cream. Participants of the study also revealed that } \\
\text { continuous use of the fairness cream made their face skin look } \\
\text { fresh, but not white. Even they believe that the use of the creams } \\
\text { could cause skin problems such as itchiness, rashes, dryness, } \\
\text { pimples, hardness and darkness of the face skin. Islam et al. (2006) } \\
\text { maintained that common skin whitening chemicals are linked with } \\
\text { negative side effects to the face skin. Skin whitening creams } \\
\text { cannot be useful without the use of skin bleaching chemicals such } \\
\text { as steroids, mercury salts, hydroquinone and other skin damaging } \\
\text { chemicals [18, 19]. According to Shankar et al. (2006) most of } \\
\text { these creams are non-prescriptive products and could potentially } \\
\text { cause face skin problems [35]. By broadcasting these types of } \\
\text { wrong information, they snatch the rights of the customer and } \\
\text { break the rules or principles of advertising copy that create } \\
\text { excitement in society. }\end{array}$ \\
\hline $\begin{array}{l}\text { 3. Different kinds of } \\
\text { Mango Juice }\end{array}$ & $\begin{array}{l}\text { "It is made with pure and fresh Mango There is no } \\
\text { preservative in it" } \\
\text { There are different types of advertising of mango } \\
\text { juice is presented in their advertisement copy that } \\
\text { juice company collect pure and fresh mango from } \\
\text { different part of the country's mango garden, those } \\
\text { fresh mangoes are processed for filling bottles and } \\
\text { providing the processed juice to the common } \\
\text { consumer over the whole world [3] [4]. }\end{array}$ & $\begin{array}{l}\text { It is no right information. According to Levine (1961) These } \\
\text { processed juices contain mainly water, sugar, preservatives, colour, } \\
\text { fruit pulps and other additives as ingredients and must maintain the } \\
\text { sanitary standard. The juices might contain different types of } \\
\text { preservatives [26]. The juices might contain different types of } \\
\text { preservatives. It is well known that the manufacturers commonly } \\
\text { use sulphur dioxide (SO2) and benzoate as preservatives in } \\
\text { processed fruit juices (BSTI, 2005) [13]. The using of high amount } \\
\text { of preservatives that had bacteriostatic effect on microbes and } \\
\text { cause health hazards for consumers (Basar \& Rahman, 2007) [7]. } \\
\text { In this case those companies deceive their customer and sales huge } \\
\text { amount of mango juice by giving wrong and unethical } \\
\text { advertisement copy. }\end{array}$ \\
\hline $\begin{array}{l}\text { 4. Many Kinds of } \\
\text { Shampoo \& Hair } \\
\text { Conditional }\end{array}$ & $\begin{array}{l}\text { "100\% hair fall is stopped Within } 14 \text { days" } \\
\text { The company also claims that their shampoo and } \\
\text { conditional give you up to } 100 \% \text { dandruff free } \\
\text { forever, Up to } 95 \% \text { less hair fall, Leaves hair up to } \\
100 \% \text { flake-free hair with a fresh scent that lasts [3] } \\
\text { [4]. }\end{array}$ & $\begin{array}{l}\text { But hear fall problem is remaining constant. It does not work } \\
\text { properly Dandruff never removes forever. Stearn ( } 2011) \text { has stated } \\
\text { that Protein-containing conditioners and shampoo only temporarily } \\
\text { fill in defects on the surface of the hair shaft, making it smoother } \\
\text { and thicker, not permanently [42]. Participants of the study also } \\
\text { revealed that continuous use of shampoo and conditional made } \\
\text { their hair smoother and thicker, but not hair fall free, dandruff free. } \\
\text { So the consumer being cheated due to false and unrealistic } \\
\text { advertising copy. }\end{array}$ \\
\hline
\end{tabular}




\begin{tabular}{|c|c|c|}
\hline $\begin{array}{l}\text { Name of the Sample } \\
\text { Products }\end{array}$ & Advertising Copy & Findings of the Study \\
\hline $\begin{array}{l}\text { 5. Vital Nutrient } \\
\text { Product }\end{array}$ & $\begin{array}{l}\text { "By taking Nutrient product you will be taller, } \\
\text { shaper and stronger". It contains } 28 \text { vital nutrients } \\
\text { and } 100 \% \text { milk protein, which increases the height } \\
{[3][4] .}\end{array}$ & $\begin{array}{l}\text { They deceive their customers by giving wrong information. It may } \\
\text { be good for health, but it does not have any change height. If every } \\
\text { child may taller by drinking this product then every person may } \\
\text { taller in the country. There will not be any short people in the } \\
\text { country. Maximum respondents experienced that Nutrient product } \\
\text { is energetic, but it cannot increase the height. So every company } \\
\text { should avoid this type of unethical practice by misleading } \\
\text { information to the customer by advertisement. }\end{array}$ \\
\hline $\begin{array}{l}\text { 6. Telecommunication } \\
\text { Operators }\end{array}$ & $\begin{array}{l}\text { "Reactive your inactive SIM and you get } 3 G \text { speed } \\
\text { 2GB internet at BDT } 9 \text { and browse free internet". } \\
\text { Use free social media or Facebook and free internet } \\
\text { browsing without any charge [4] [5]. }\end{array}$ & $\begin{array}{l}\text { When a customer takes this offer, they experience that internet } \\
\text { speed is too low at below } 100 \mathrm{kbps} \text { and it is under } 2 \mathrm{G} \text { speeds. } \\
\text { When customers try to download any items, they found that that } \\
\text { offer is not a free service and charge is applicable. Most of the } \\
\text { mobile phone operators deceive their customers by giving wrong } \\
\text { information. When customers are browsing free Facebook \& } \\
\text { internet they found, their account balance is zero and Cut money } \\
\text { from their balance accounts. The company has auto renewed any } \\
\text { service package without informing to their customer and Cut } \\
\text { money from their mobile accounts. Some company says that they } \\
\text { give lowest call rate by imposing Taxes and VAT to the customer. } \\
\text { So they do not give lowest call rat. Customers are thinking that like } \\
\text { most mobile operator companies are cheating on them. } \\
\text { Telecommunication companies are providing wrong and Fraud } \\
\text { information to the customer by an advertisement which is } \\
\text { unethical. }\end{array}$ \\
\hline $\begin{array}{l}\text { 7. Different kinds of Face } \\
\text { Wash }\end{array}$ & $\begin{array}{l}\text { "100\% prevent your pimples and make your skin } \\
\text { clean, fresh, and glowing within } 14 \text { days" } \\
\text { Its } 100 \% \text { soap free formula has a rich lather that } \\
\text { gently } 100 \% \text { remove dead cells, impurities, acne and } \\
\text { pimples, kill problem- causing bacteria within } 14 \\
\text { days. This face wash activated carbon to easily absorb } \\
\text { and lift away the black dirt and impurities from skin } \\
\text { surface and deep within poses, helping to reduce the } \\
\text { causes of blemish and excessive oil, leaving your skin } \\
\text { radiant, clean and smooth, Prevents outbreaks and the } \\
\text { recurrence of acne, to help reveal your glowing and } \\
\text { natural pure white looking skin [3] [4]. }\end{array}$ & $\begin{array}{l}\text { Most of these creams are non-prescriptive products and could } \\
\text { potentially cause facial skin problems. So the information of their } \\
\text { advertisement copy is false, confusing and baseless. According to } \\
\text { Shankar et al. (2006) most of these creams are non-prescriptive } \\
\text { products and could potentially cause face skin problems [35]. So } \\
\text { the information of their advertisement copy is false, confusing, and } \\
\text { baseless. By broadcasting these types of wrong information, they } \\
\text { snatch the right of the customer and break the rules or principles of } \\
\text { advertising copy create excitement in society. These are deceptive } \\
\text { activities. All kinds of cosmetics are harmful for our skin. But they } \\
\text { never say it in their advertisement copy or make customers } \\
\text { conscious about this. }\end{array}$ \\
\hline
\end{tabular}

\section{Recommendations}

The review of existing literature, findings and suggestion made by the experts or respondents helped the researchers to find out ways and means of improving unethical advertising in Bangladesh. Ethical behavior within the business sector is very important; the mere earning of profit should not be the sole driving activity of an organization. If management establishes fair, proper rules and regulations, including an equitable reward and punitive system for personnel on the basis of their competence, ethical standards, discourage corruption and bribery, then ethics in the business process can be improved. At the time of conducting marketing activities and advertising activities, every company should follow the business ethics values, marketing philosophy and societal marketing philosophy. They need to work for the betterment of society and the long run managing community interest. They should be provided the perfect information on advertising of copy to the customer that can increase the credibility of general people. The Marketer should try to gain the morality and credibility besides gaining the profit. They should help to establish the consumer's right in Bangladesh.
All advertising must be free, fair and credible towards the target audience. The ethical and truthful advertising is the key to ensure relationship and sustainable marketing. It also ensures social safety and security. That helps to build up a better marketing environment which is good both for sellers and buyers groups. Other recommendations to improve ethical standards and norms in the business sector follow:

1. The Bangladesh Government has undertaken a number of reforms with the intent of monitoring, controlling and diminishing the prevalence of corruption and unethical practice in advertising and society at large.

2. Companies must have to maintain the social responsibility and should follow the rules and related laws of advertising in Bangladesh.

3. Bangladesh Government should establish a selfregulatory voluntary organization of the advertising industry 'Advertising Standards Council of Bangladesh (ASCB). Their objective will be that all advertising material must be truthful, legal and honest, decent and not objectify women, safe for consumers, especially children and last but not the least, fair to their competitors. 
4. Advertising agency and advertiser should avoid the confusion and false information about products, services even that are profitable for short terms.

5. Company should consider the customers right and to do work accordingly.

6. Develop the right principles of advertising and try to maintain it and if broken any one than arrange penalty immediately.

7. To implant fair business practices towards consumers by informing advertisers and advertisement producers about their duties and responsibilities to consumers.

8. Moral education should be emphasized, particularly, innovative practices aimed at promoting a high standard of morals and ethics in business. Training institutes should be encouraged to arrange training courses, workshops and conferences on business ethics.

9. To increase publicity in relation to contradict the misleading statements in the media.

10. More awareness is to be created and the board has to function effectively and ban all advertisements which do not follow the ethics.

11. Socially and economically boycott or reject all types of misleading, false, irritating and untruthful advertising.

12. Bangladesh Standards and Testing Institution (BSTI) should monitor strictly about the misleading advertising which is circulated in Bangladesh.

13. Consumers Association of Bangladesh (CAB) should measure the effectiveness of all advertising weekly or monthly and take necessary action against the unethical practices.

14. Codes of ethics should be developed and utilized to motivate personnel, increase their capability, judgment power, and effective managerial skill. Personnel subject to professional and ethical codes of conduct of their respective organization should be encouraged to adhere to those codes.

15. Media and public financial organization should be careful to prevent unethical advertising and be active to circulate all fair advertising.

By maintaining the above mentioned recommendations and suggestions the marketers should broadcast or telecast their advertisement. Then the country, society, nation and entire world will be benefited. It may help to increase the good will of the company by developing positive, harmony, perfection and ethical advertising.

\section{Conclusion}

It is clear that unethical practices in advertising may often occur in the most areas in Bangladesh. One lesson that we should understand is that most companies seem to be engaged in unethical practices and can therefore misleading the consumer. Many firms even they are assigned to behave ethically, but their practices show irregularities and frauds.
According to this, the unethical advertising practices occurrence characteristics in modern society are: the criteria's of justice, integrity, honesty and the eligibility, noncompliance, the creation of a false impression, the presentation of false and inaccurate facts, the conversion of social values of products, the manipulation of impulsive consumers, the control of subconsciousness, the impact on persons economic behavior or possibility of the impact. Advertising copy is the most important part of any advertising. So every company or advertising agency should provide correct information to their customers by advertising copy. Advertising copy must be ethical and credible. Informative, correct, creative and beautiful advertising makes a good effect on the economy of the country. The marketer should try to gain the morality and credibility besides gaining the profit. We hope that every company will respect all the advertising rules \& regulation and maintain or honor consumer right's. They can gain profit by giving the informative, correct, credible information to consumer and developed the society with morality.

\section{Acknowledgements}

I'm Md. Nekmahmud Argon, BBA Student, Department of Marketing, Begum Rokeya University Rangpur, Bangladesh. At first, I would like to bow my head to the Almighty Allah for keeping me physically and mentally fit for the completion of my research work. I owe a special kind of debt to my dear loving parents Md. Mahabub Alam and Farida Yesmin for their greatest contribution in my life. I would like to express my deepest respect and thanks to my respected teacher and advisor Sheik Majedul Huq, Assistant professor, Department of Marketing, Begum Rokeya University Rangpur for giving me valuable direction and suggestions about this research. I'm also very grateful to my university sir, and friends for their nice cooperation and inspiration about the research work.

\section{References}

[1] Abbasi, A. S., Akhter, W., \& Umar, S. (2011). Ethical issues in advertising in Pakistan: An Islamic perspective. World Applied Sciences Journal, 13 (3), 444-452.

[2] Abideen, E. P., Sainul., \& Muraleedharan, K. P. (1998). Ethical and Social Issues in Advertising. Abhigyan, 16 (4), 3941.

[3] Advertise telecast on various TV channel in Bangladesh.

[4] Advertise given in all Mass Media in Bangladesh.

[5] Advertisng given in online and social Media in Bangladesh.

[6] AJAY, V (2014). Perception of Indian Consumers towards Indian Advertisements. International Journal of Research in Humanities, Arts and Literature, 2(2), 89-114.

[7] Basar, M. A., \& Rahman, S. R. (2007). Assessment of microbiological quality of processed fruit juice. Bangladesh Journal of Microbiology, 24(2), 166. 
[8] Baumhart, R. (1968). Ethics in business. Holt, Rinehart and Winston.

[9] Belch, G and Belch M. (2009). Advertising and Promotion (9th ed.). Mac Grow Hills.

[10] Bin Nooh, M. N., Khairi, K. F., Ab Aziz, M. R., Abdullah, M., \& Shukor, S. A. (2014). The Criteria and Challenges of Unethical Advertising. American Journal of Business, Economics and Management, 2 (4), 88.

[11] Bongiorno, R., Bain, P. G., \& Haslam, N. (2013). When Sex Doesn't Sell: Using Sexualized Images of Women Reduces Support for Ethical Campaigns.

[12] Boulstridge, E., \& Carrigan, M. (2000). Do consumers really care about corporate responsibility? Highlighting the attitudebehavior gap. Journal of Communication Management, 4 (4), 355-68.

[13] BSTI. (2005). Bangladesh Standard Specification for Drinking Water. BDS 11150. Bangladesh Standard and Testing Institute (BSTI). Dhaka.

[14] Business Ethics (Stanford Encyclopedia of Philosophy). Plato. stanford. edu. 2008-04-16. Retrieved 2013-06-04.

[15] Creyer, E. H., \& Ross, W. T. (1997). The influence of firm behavior on purchase intention: do consumers really care about business ethics?. Journal of Consumer Marketing, 14 (6), 421-33.

[16] Dragon International (1991), Corporate Reputation: Does the Consumer Care? Dragon International, London.

[17] Giebelhausen, M., and Novak, T. (2011). Web advertising: Sexual content on eBay. Journal of Business Research, 65 (2012) 840-842, 840.

[18] Islam, K. S., Ahmed, H. S., Karim, E., \& Amin, A. M. (2006, May 12). Fair Factor. Star Weekend Magazine.

[19] Islam, K. S., Ahmed, H. S., Karim E., \& Amin, A. M. Fair factor. (2006, December 9). The whiter the better. http://www.thedailystar.net/magazine/2 006/05/02/cover.htm.

[20] Jahan, T. (2010). Ethics In Marketing On Bangladesh Perspective: Study On Few Companies Of Bangladesh. World Journal of Management, 2 (2), 95-108.

[21] Kabir, M. (2013). Unethical practices of advertising in Bangladesh. Academic journal of Siddheswari Girl's College.

[22] Kotler, P. (2012, March 1). Bangabandhu International Conference Center, Dhaka, Bangladesh.

[23] Kotler, P., \& Armstrong, G. (2010). Principles of marketing. Pearson Education.

[24] Kotler, P. (2009). Marketing management: A south Asian perspective. Pearson Education India.

[25] Larkin \& Ernest, F. (1977). A Factor Analysis of College Student Attitude toward Advertising. Journal of Advertising, $6(2), 42-46$.

[26] Levine M. (1961). Facts and fancies of bacterial indices in standards for water and foods. Food Technol. 15(2), 29-34.

[27] Liepinyte, M., \& Daugèlienè, R. (2012). Interrelation of misleading advertising and solutions of consumers: legal regulation and institutional background in lithuania. European Integration Studies, (6), 192-201.
[28] Long, D. (2011). Unethical Practice in Business: the Development of a Framework for Thematic Analysis. Verslo ir teisès aktualijos/Current Issues of Business and Law, 1, 46-52.

[29] Maleki, M., \& Pasha, M. A. (2012). Ethical Challenges: Customers' Rights. SCMS Journal of Indian Management, 9(4), 5.

[30] Malhotra, N. K. \& Dash, S. (2011). Marketing Research: An Applied Orientation ( $6^{\text {th }}$ ed.). Pearson, Delhi.

[31] Menci, D., Righini, F. M., Cameli, M., Lisi, M., Benincasa, S., Focardi, M., \& Mondillo, S. (2013). Acute effects of an energy drink on myocardial function assessed by conventional echoDoppler analysis and by speckle tracking echocardiography on young healthy subjects. Journal of amino acids.

[32] Olson, Erik L. (1995). How Magazine Articles Portrayed Advertising from 1900 to 1940. Journal of Advertising, 24 (3), 199-215.

[33] Ramachandran \& Venkatesh, S. (2012). Marketing MIX: An Area of Unethical Practices? Middle-East Journal of Scientific Research 12 (12), 1644-1645.

[34] Sengupta, J., and Dahl, D. (2007). Gender-related reactions to gratuitous sex appeals in advertising. Journal of Consumer Psychology 18 (2008) 62-78, 65.

[35] Shankar, P. R., Giri, B. R., \& Palaian, S. (2006). Fairness creams in South Asia-a case of disease mongering. PLoS Med, 3 (7), e315.

[36] Simon, F. L. (1995). Global corporate philanthropy: a strategic framework. International Marketing Review, Vol. 12 No. 4, pp. 20-37.

[37] Singh, M.(2014). ETHICAL ISSUES AND PRINCIPLES RELATED TO ADVERTISING. Abhinav-National Monthly Refereed Journal of Research In Commerce \& Management (Online ISSN 2277-1166), 3(6), 100-108.

[38] Singal, R., \& Kamra, G. (2012). Ethical issues in advertising. International Journal of Engineering, Science and Metallurgy, 2(3), 689-694.

[39] Singh, J., \& Sandhu, N. (2011). Impact of television commercials on the social and moral behavior of Indian viewers-empirical evidence. International Journal of Humanities and Social Science, 1 (7), 178-187.

[40] Singh, R., \& Vij, S. (2007, April). Socio-Economic and Ethical Implications of Advertising-A Perceptual Study. In International Marketing Conference on Marketing \& Society, April (pp. 8-10).

[41] Smith, R. G. (2000). DECEPTIVE AND MISLEADING ONLINE ADVERTISING AND BUSINESS PRACTICES. In Communications Research Forum (Vol. 2000).

[42] Stearn, M. (2011, October 5). Wednesday, http://www./ My Research Paper/Shampoo/Hair loss.htm.

[43] Treise, D., Weigold, M. F., Conna, J., \& Garrison, H. (1994). Ethics in advertising: Ideological correlates of consumer perceptions. Journal of Advertising, 23(3), 59-69.

[44] Usman, M., Ilyas, S., Hussain, M. F., \& Qureshi, T. M. (2010). General attitude towards advertising: Cultural influence in Pakistan. International Journal of Marketing Studies, 2 (2), p124. 
[45] Wilkie., \& William L. (1990). Consumer Behavior ( $2^{\text {nd }}$ ed.). John Wiley \& Sons, New York.

[46] Zetterqvist, A. V., \& Mulinari, S. (2013). Misleading advertising for antidepressants in Sweden: a failure of pharmaceutical industry self-regulation.

\section{Biography}

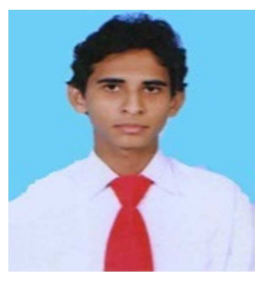

Md. Nekmahmud Argon (Author) is a BBA final year student of the Marketing Department at Begum Rokeya University, Rangpur, Bangladesh. He is the youngest son of Md. Mahabub Alam and Farida Yesmin. His research interest areas include Advertising, Agriculture Marketing, Consumer Behavior, Green Marketing, Global Marketing and Emarketing. He has conducted research on Customer's Attitude towards Mobile Advertising in Bangladesh which is published in International Journal of Business and Economics Research, USA. Nekmahmud is currently researching on different areas of Marketing with his academic studies.

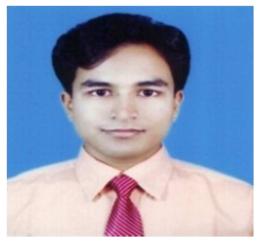

Sheikh Majedul Huq (Supervisor) (BBA \& MBA major in Marketing, University of Rajshahi, Bangladesh) is presently an assistant professor and head of the Marketing Department at Begum Rokeya Uiversity, Rangpur, Bangladesh. He spends his time with teaching, motivational training and research works. $\mathrm{He}$ has been teaching with marketing related subject in the university level form 2007. He is also the editor of journal of Business Research, bi-annual business journal under the faculty of Business studies, BRUR, Bangladesh. An interested and active researcher in the area of Consumer Behavior, Touris Marketing, Advertising and SME development. Recently he has been submitted his M. Phil degree for awarding.

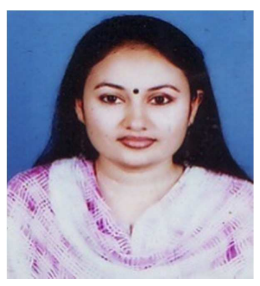

Mst. Shuly Aktar (Coauthor) is presently lecturer of the Marketing Department at Begum Rokeya Uiversity, Rangpur, Bangladesh. She has received her BBA \& MBA degree from the Marketing Department at University of Rajshahi, Bangladesh. 